\title{
PHYTOEXTRACTION AND FRACTIONATION OF HEAVY METALS IN SOILAFTER MULTIPLE APPLICATIONS OF NATURAL CHELANTS
}

\author{
Évio Eduardo Chaves de Melo ${ }^{1}$; Clístenes Williams Araújo do Nascimento ${ }^{1 *}$; Adriana Maria \\ de Aguiar Accioly ${ }^{2}$; Ana Cristiane Queiroz Santos ${ }^{1}$ \\ ${ }^{1}$ UFRPE - Depto. de Agronomia - R. Dom Manuel de Medeiros, s/n - Dois Irmãos - 52171-900 - Recife, PE - \\ Brasil. \\ ${ }^{2}$ Embrapa Mandioca e Fruticultura Tropical - Embrapa, s/n-44380-000 - Cruz das Almas, BA - Brasil. \\ *Corresponding author <clistenes@pq.cnpq.br>
}

\begin{abstract}
Chelate-assisted phytoextraction of heavy metals is a promising approach to clean up polluted soils. However, the most successful chelants tested so far are synthetic agents that barely degrade in soil, increasing the metal leaching risks. Natural organic acids have been proposed to enhance phytoextraction due to their higher biodegradability, but they can also be a drawback for efficient phytoextraction. This work was carried out to compare the effectiveness of multiple applications of citric and gallic acids on the availability in soil and accumulation of $\mathrm{Cd}, \mathrm{Pb}, \mathrm{Cu}$, and $\mathrm{Zn}$ by velvet bean (Stizolobium aterrimum) plants. The organic acids were added as follows: $5 \mathrm{mmol} \mathrm{kg}^{-1}$ in the $28^{\text {th }}$ cultivation day; two doses of $5 \mathrm{mmol} \mathrm{kg}^{-1}$ at the $28^{\text {th }}$ and $31^{\text {st }}$ day; and three applications at the same rate at the $28^{\text {th }}$, $31^{\text {st }}$, and $34^{\text {th }}$ day of velvet bean cultivation. Soil samples were sequentially extracted and soil solution metal concentrations assessed. Neither citric acid nor gallic acid was efficient for metals phytoextraction. In general, low molecular weight organic acids (LMWOA) application increased the metal concentrations in the water soluble and exchangeable fractions. Zinc and $\mathrm{Cu}$ were retained mostly in the organic matter fraction. Zn was remobilized from the organic matter fraction through LMWOA application into the water soluble and exchangeable fractions. LMWOA mobilized $\mathrm{Pb}$ and $\mathrm{Cu}$ from iron oxides, but such an increase in solubility was not high enough to affect phytoextraction.
\end{abstract}

Key words: phytoremediation, soil pollution, soil remediation, organic acids

\section{FITOEXTRAÇÃO E FRACIONAMENTO DE METAIS PESADOS EM SOLOAPÓS MÚLTIPLAS APLICAÇÕES DE ÁCIDOS ORGÂNICOS}

\begin{abstract}
RESUMO: Fitoextração de metais induzida por quelantes é uma técnica promissora para despoluição de solos. Entretanto, os quelantes mais eficientes são sintéticos e apresentam baixa taxa de biodegradação, o que aumenta o risco de lixiviação de metais. Ácidos orgânicos têm sido propostos para auxiliar na fitoextração, mas a sua rápida degradação pode ser limitante para a eficiência desta técnica. O objetivo do trabalho foi comparar a eficiência de aplicações sucessivas dos ácidos cítrico e gálico, na disponibilidade, absorção e acumulação de $\mathrm{Cd}, \mathrm{Pb}, \mathrm{Cu}$ e $\mathrm{Zn}$ pela mucuna preta (Stizolobium aterrimum). $\mathrm{O}$ solo foi contaminado com $\mathrm{Cd}, \mathrm{Pb}, \mathrm{Cu}$ e $\mathrm{Zn}$ nas doses 20, 150, 100 e $150 \mathrm{mg} \mathrm{kg}^{-1}$, respectivamente, e cultivados por 35 dias. Os ácidos foram aplicados de três formas: uma aplicação de $5 \mathrm{mmol} \mathrm{kg}{ }^{-1}$ no $28^{\circ}$ dia de cultivo da mucuna; duas aplicações de $5 \mathrm{mmol} \mathrm{kg}^{-1}$ no $28^{\circ}$ e $31^{\circ}$ dia; e três aplicações de $5 \mathrm{mmol} \mathrm{kg}{ }^{-1}$ no $28^{\circ}, 31^{\circ}$ e $34^{\circ}$ dia de cultivo. As amostras de solo foram submetidas à extração e fracionamento químicos. Os ácidos orgânicos testados não foram eficientes na indução da fitoextração. Em geral, a aplicação dos ácidos aumentou as concentrações de metais tanto nas frações solúveis como em água e também na trocável. Zinco e cobre ficaram retidos principalmente na fração matéria orgânica. O Zn, após aplicação dos ácidos, foi remobilizado da fração matéria orgânica para as frações solúvel em água e trocável. Os ácidos orgânicos mobilizaram $\mathrm{Pb}$ e $\mathrm{Cu}$ dos óxidos de ferro, mas este aumento na solubilidade não foi suficiente para favorecer a fitoextração.

Palavras-chave: fitorremediação, poluição do solo, remediação do solo, ácidos orgânicos
\end{abstract}

\section{INTRODUCTION}

Environmental restoration of polluted soils by conventional technologies demands large economic re- sources (Cunningham \& Berti, 2000; Ensley, 2000; Nascimento \& Xing, 2006). Thus a more affordable approach to decontaminate soils are increasingly gaining interest. Phytoextraction - the use of plants to remove 
metals from soils by storing them in above-ground biomass - has been developed as an economically and environmentally attractive technology to decontaminate heavy metal polluted soils (Raskin et al., 1997; Terry $\&$ Bañuelos, 2000). So far, two phytoextraction strategies have been developed. The first one is the use of hyperaccumulating plants that naturally concentrate metals in their aboveground tissues. The other strategy makes the use of high biomass plants that are induced to accumulate metals through chelants applications in soils (Blaylock et al., 1997; Huang et al., 1997; Cooper et al., 1999; Wu et al., 1999; Shen et al., 2002; Melo et al., 2006). The main drawback for the public acceptance of this technique is the risk that synthetic chelants pose to environment due to a possible excessive metal solubilization and consequent leaching (Shen et al., 2002; Chen et al., 2003).

The use of low molecular weight organic acids (LMWOA) which are easily biodegradable has been proposed as an alternative to the synthetic chelants. However, many authors have found low effectiveness of LMWOA on inducing metals accumulation in plants (Lombi et al., 2001; Kos \& Lestan, 2004; Wu et al. 2004; Nascimento et al., 2006). This low LMWOA effectiveness has been attributed to their rapid mineralization by soil microorganisms (Krishnamurti et al., 1997; Römkens et al., 2002; Meers et al., 2005). For instance, Ström et al. (2001) reported that one third of citric acid added to soil was degraded after a 24hour period.

Taking into account the low efficiency of a single application of LMWOA on phytoextraction enhancement, we studied the effect of multiple applications of citric and gallic acids on the phytoextraction of $\mathrm{Cd}, \mathrm{Pb}, \mathrm{Cu}$, and $\mathrm{Zn}$ by velvet bean plants (Stizolobium aterrimum). Additionally, a soil fractionation was performed to determine the metal soil pools most affected by organic acids and how this effect can be related to the phytoextraction.

\section{MATERIAL AND METHODS}

The soil material used in this study was classified as Ustic Kandihumult. Selected chemical and physical properties of the soil are: $\mathrm{pH}=4.3$ (water/soil 1:2.5); exchangeable acidity $=8.2\left(\mathrm{Al}\right.$, in $\left.\mathrm{mmol}_{\mathrm{c}} \mathrm{dm}^{-3}\right)$; exchangeable basis $=5.5(\mathrm{Ca}$ and $\mathrm{Mg}$, respectively in $\mathrm{mmol}_{\mathrm{c}} \mathrm{dm}^{-3}$ ) and 5.0 ; extractable phosphorus $=12.0 \mathrm{mg}$ $\mathrm{dm}^{-3}$; exchangeable potassium, sodium and total activity $=0.5,1.4$ and 49.5, respectively, (in $\mathrm{mmol}_{\mathrm{c}} \mathrm{dm}^{-3}$ ); organic matter $=566 \mathrm{~g} \mathrm{~kg}^{-2}$; and sand, silt and clay (in $\left.\mathrm{g} \mathrm{kg}^{-1}\right)=566,48$ and 386, respectively.

The soil sample was air dried, passed through a $2 \mathrm{~mm}$ sieve and limed to $\mathrm{pH} 6.5-7.0$ with carbon- ates of $\mathrm{Ca}$ and $\mathrm{Mg}$ (3:1 molar ratio solution) before further use. Samples of $1 \mathrm{~kg}$ were amended with $\mathrm{CdCl}_{2}, \mathrm{PbCl}_{2}, \mathrm{CuSO}_{4} .5 \mathrm{H}_{2} \mathrm{O}$, and $\mathrm{ZnCl}_{2}$ to achieve the concentrations of 20,150,100, and $150 \mathrm{mg} \mathrm{kg}^{-1}$ of $\mathrm{Cd}, \mathrm{Pb}, \mathrm{Cu}$, and $\mathrm{Zn}$, respectively. These metal concentrations were chosen to simulate a soil moderately polluted, assuming that phytoextraction would be an appropriate technique. The metal-amended samples were kept incubated for a 30 -day period at $80 \%$ of the water holding capacity. The samples of the soil material were fertilized as follows: 250, 240, 150, and $100 \mathrm{mg} \mathrm{kg}^{-1}$ of $\mathrm{N}, \mathrm{P}, \mathrm{K}$, and $\mathrm{S}$, respectively, added as $\mathrm{NH}_{4} \mathrm{SO}_{2}, \mathrm{NH}_{4} \mathrm{H}_{2} \mathrm{PO}_{4}$, and $\mathrm{KNO}_{3}$; micronutrients $\mathrm{Fe}$ $\left(\mathrm{FeSO}_{4} .7 \mathrm{H}_{2} \mathrm{O}\right), \mathrm{Mn}\left(\mathrm{MnCl}_{2} \cdot 4 \mathrm{H}_{2} \mathrm{O}\right), \mathrm{B}\left(\mathrm{H}_{3} \mathrm{BO}_{3}\right)$, and $\mathrm{Mo}$ $\left(\mathrm{Na}_{2} \mathrm{MoO}_{4} \cdot 2 \mathrm{H}_{2} \mathrm{O}\right)$ were applied at the concentrations of 2, 4, 1, and $0.2 \mathrm{mg} \mathrm{kg}^{-1}$, respectively. Then, the samples were transferred into plastic pots set as a greenhouse experiment.

The soil samples in the pots were cultivated for 35 days with velvet bean (Stizolobium aterrimum), a high biomass green manure species. Velvet bean was chosen because its potential for metal accumulation when grown on a soil contaminated with heavy metals as compared to seven other high biomass producing species (Santos, 2006). This species has been also reported as tolerant to herbicides (Procópio et al., $2005)$. Plants were watered to $80 \%$ of their water holding capacity on a daily basis by weighing the pots and adding water to replace any weight loss. Two LMWOA, citric acid (aliphatic) and gallic acid (aromatic), were applied to the samples at a $5 \mathrm{mmol} \mathrm{kg}{ }^{-1}$ rate in three ways: a single application at the $28^{\text {th }}$ day of growing; two applications at the $28^{\text {th }}$ and $31^{\text {st }}$ day; and three successive applications at the $28^{\text {th }}, 31^{\text {st }}$, and $34^{\text {th }}$ growing day. A control pot (contaminated soil with no LMWOA application) and a blank (soil with no metals neither LMWOA) were used to test the effects of LMWOA and metals on the plant dry matter production.

To study the effects of chelants on the solubilization of the soil metals, one soil moisture sampler (Rhizon ${ }^{\circledR}$ SMS: Rhizosphere Research Products, Eijkelkamp, The Netherlands) was placed in the center of each pot. Soil solution was sampled by pressure suction in a syringe at the following day each chelant addition. The concentration of metals in the soil solutions were summed up.

Plants were harvested at the $35^{\text {th }}$ day of growing by cutting the shoots on the soil surface and the total shoot dry biomass was determined for each pot. The soil was then broken up and roots were harvested by hand. The roots were abundantly washed in tap water until free of soil and then washed with distilled water and dried in an oven at $70^{\circ} \mathrm{C}$. Both shoot and 
root dried materials were further ground and digested in a mixture of $\mathrm{HNO}_{3}: \mathrm{HClO}_{4}(3: 1 \mathrm{v} / \mathrm{v})$. The concentrations of $\mathrm{Cd}, \mathrm{Pb}, \mathrm{Cu}$, and $\mathrm{Zn}$ in the extracts were determined by atomic absorption spectrometry. The net removal of metals was calculated by multiplying the concentration of metals in the shoots by the biomass.

Water soluble metals were extracted by $\mathrm{CaCl}_{2}$ $0.01 \mathrm{~mol} \mathrm{~L}^{-1}$ according to Novozamsky et al. (1993). The metal contents in the exchangeable fractions, organic matter, and crystalline iron oxides were determined based on Shuman (1985), whereas the amorphous iron oxides fraction was extracted according to Chao \& Zhou (1983). The fractionation method consisted of the following steps: (1) Water soluble (WS) - 5.0 grams of soil were placed in a $50-\mathrm{mL}$ centrifuge tube in which were added $20 \mathrm{~mL}$ of $\mathrm{CaCl}_{2} 0.01 \mathrm{~mol}$ $\mathrm{L}^{-1}$. The mixture was agitated for $2 \mathrm{~h}$ and centrifuged for $10 \mathrm{~min}$ at $2000 \times \mathrm{g}$. The supernatant was filtered and separated. The fractionation continued for the remaining sample in the tube; (2) Exchangeable Fraction (Ex) - $20.0 \mathrm{~mL}$ of $1 \mathrm{~mol} \mathrm{~L}^{-1} \mathrm{Mg}\left(\mathrm{NO}_{3}\right)_{2}$ were added to the tube and the set was agitated for two hours, the mixture was then centrifuged for $10 \mathrm{~min}$ at 2,000 $\times g$ and the supernatant filtered and separated; 20.0 $\mathrm{mL}$ of distilled water was added; then another agitation was performed for 3 min followed by a new centrifugation, and the supernatant filtered and separated again. The two supernatant liquids were combined and stored for analysis. The sequential extraction continued for the remaining soil sample; (3) Organic Matter Fraction $(\mathrm{OM})-10.0 \mathrm{~mL}$ of $\mathrm{NaClO}, 5-6 \%$ at $\mathrm{pH}$ 8.5, were added to the Ex-free sample; the system was heated to $100^{\circ} \mathrm{C}$ for $30 \mathrm{~min}$, and agitated periodically; thereafter, the sample was centrifuged, and the supernatant was filtered. This procedure was repeated twice, and the three separated supernatants were combined. Ten $\mathrm{mL}$ of distilled water were added in the centrifuge tube, and after shaking for $3 \mathrm{~min}$, it was centrifuged, filtered, and the separated supernatant was added to the three combined extracts from the $\mathrm{NaClO}$ extraction and stored for analysis. The sequential extraction continued for the remaining soil sample; (4) Amorphous Iron Oxide Fraction (AFeOx) - 30.0 mL of $\mathrm{NH}_{2} \mathrm{OH} . \mathrm{HCl}$ (hydroxylamine hydrochloride), $0.1 \mathrm{~mol}$ $\mathrm{L}^{-1}$ plus $\mathrm{HCl} 0.25 \mathrm{~mol} \mathrm{~L}^{-1}$, at $\mathrm{pH} 3.0$, were added to the OM-free soil sample, and the mixture agitated for $30 \mathrm{~min}$, centrifuged and filtered; the separated supernatant was stored for analysis. To continue the sequential extraction, $15 \mathrm{~mL}$ of distilled water were added to the centrifuge tube and shaken for $3 \mathrm{~min}$. The supernatant was then discarded; (5) Crystalline Iron Oxide Fraction $(\mathrm{CFeOx})-30.0 \mathrm{~mL}$ of $\left(\mathrm{NH}_{4}\right)_{2} \mathrm{C}_{2} \mathrm{O}_{4}$ (ammonium oxalate), $0.2 \mathrm{~mol} \mathrm{~L}^{-1}+\mathrm{H}_{2} \mathrm{C}_{2} \mathrm{O}_{4}$ (oxalic acid) 0.2 mol L-1 + ascorbic acid $0.01 \mathrm{~mol} \mathrm{~L}^{-1}$, at $\mathrm{pH} 3.0$, were added to the AFeOx-free soil sample, the mixture was heated to $100^{\circ} \mathrm{C}$ for $30 \mathrm{~min}$, agitated periodically, and thereafter was centrifuged and filtered; the separated supernatant was stored for analysis.

The experiment was arranged in a completely randomized design. All the data comprise averages of three replicates. Data were statistically evaluated by the ANOVA and significantly different means assessed by the Scott-Knot test.

\section{RESULTS AND DISCUSSION}

Plants produced less biomass on the heavy metal contaminated soil when no acids were added (control pot) as compared to the ones grown on the non-contaminated soil (Table 1). The metal phytotoxicity induced a $79 \%$ reduction in the root growth and $86 \%$ in the shoots. Of course, such a reduction in biomass production can be a drawback for efficient phytoextraction. Toxicity symptoms such as chlorosis and necrosis were observed during the plants growth in all the pots with contaminated soil, even before chelants application.

Except for gallic acid applied three times, LMWOA did not reduce the plants dry matter production (Table 1). Luo et al. (2005); Tamura et al. (2005) and Evangelou et al. (2006) also found that citric acid application did not affect the shoots dry matter production, which indicates the lower phytotoxicity of this organic acid. Citric acid could be successively applied on field conditions aiming to hasten metal phytoextraction without affecting shoot biomass. As it will be discussed later, three applications of citric acid can be effective in removing metals from soil, especially owing to its low toxicity to shoots. Gallic acid, on the other hand, can be applied up to two times at a $5 \mathrm{mmol} \mathrm{kg}{ }^{-1}$ dose without decreasing the shoots dry matter of the plants, but with little effect on metal removal from soils.

The LMWOA increased the heavy metal concentrations in the soil solution (Figure 1), but gallic acid solubilized a much smaller amount of metals than citric acid. Nascimento et al. (2006) also reported that citric acid was more efficient to solubilize $\mathrm{Zn}$ and $\mathrm{Cu}$ in soil than gallic acid. This was probably due to the lower solubility of gallic acid in soil. However, it should be noted, that the concentrations of $\mathrm{Pb}$ and $\mathrm{Cu}$ brought into solution by citric acid were lower than $\mathrm{Cd}$ and $\mathrm{Zn}$, which probably results from the differences on solubility of such metal compounds in soils. The concentrations of $\mathrm{Cd}, \mathrm{Zn}$, and notably $\mathrm{Pb}$ and $\mathrm{Cu}$ in soil solution increased linearly following the successive applications of citric acid. 
Table 1 - Dry matter production of velvet bean roots and shoots after chelants successive applications to a metal multicontaminated soil material.

\begin{tabular}{|c|c|c|c|c|c|c|c|}
\hline \multirow{2}{*}{ Blank } & \multirow{2}{*}{ Control } & \multicolumn{3}{|c|}{ Citric acid } & \multicolumn{3}{|c|}{ Gallic acid } \\
\hline & & 1 Appl. & 2 Appl. & 3 Appl. & 1 Appl. & 2 Appl. & 3 Appl. \\
\hline . &  & 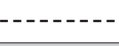 & --- & ot --.- & $-\cdots$ & 然 & $\ldots$ \\
\hline \multicolumn{8}{|c|}{ Roots } \\
\hline $3.41 \mathrm{a}$ & $0.69 \mathrm{c}$ & $0.66 \mathrm{c}$ & $0.61 \mathrm{c}$ & $0.67 \mathrm{c}$ & $0.81 \mathrm{~b}$ & $0.81 \mathrm{~b}$ & $0.57 \mathrm{c}$ \\
\hline \multicolumn{8}{|c|}{ Shoots } \\
\hline $10.47 \mathrm{a}$ & $1.42 \mathrm{~b}$ & $1.37 \mathrm{~b}$ & $1.50 \mathrm{~b}$ & $1.48 \mathrm{~b}$ & $1.56 \mathrm{~b}$ & $1.50 \mathrm{~b}$ & $0.99 \mathrm{c}$ \\
\hline
\end{tabular}

Values followed by the same letter in lines are not different (Scott-Knott com $P<0.05$ ).

Cadmium



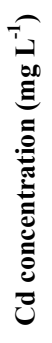

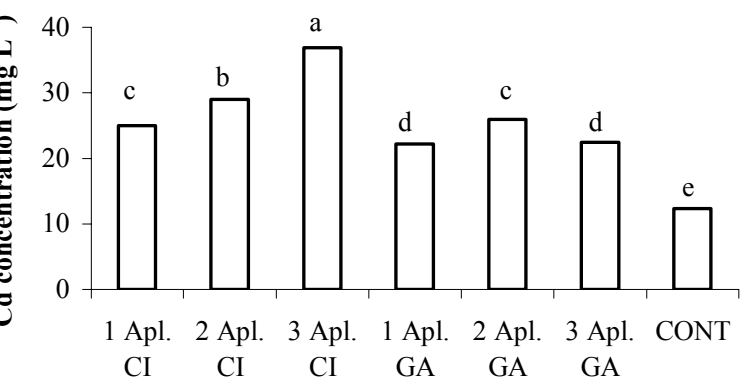

Chelant

Copper

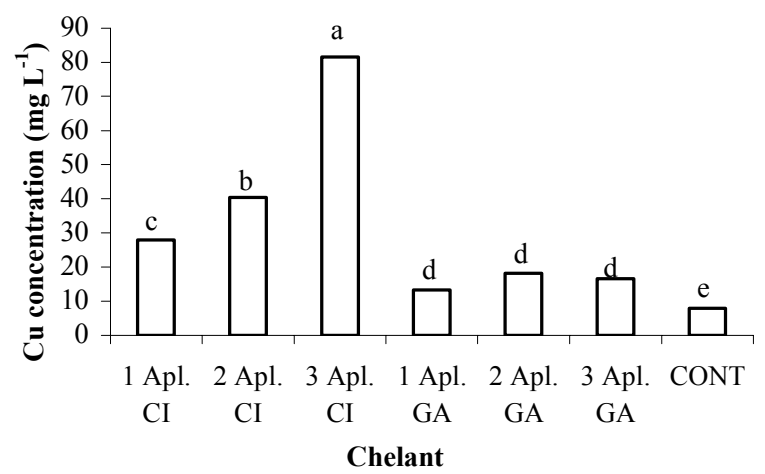

Lead

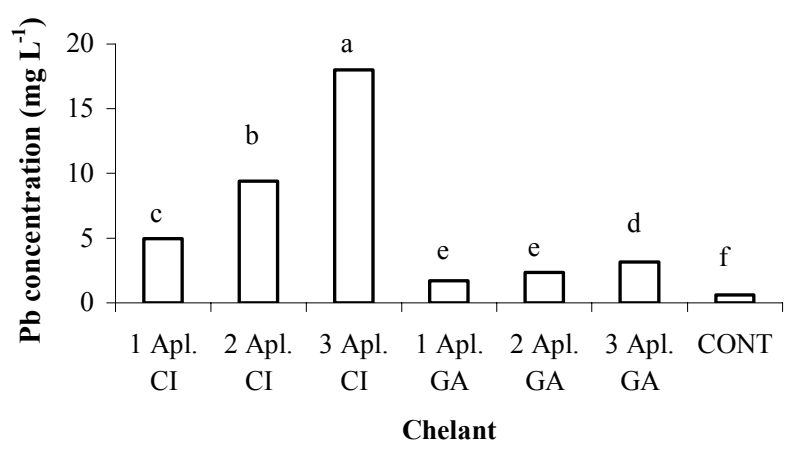

Zinc



Figure 1 - Concentrations of $\mathrm{Cd}, \mathrm{Pb}, \mathrm{Cu}$, and $\mathrm{Zn}$ in soil solution as a result of three successive applications of citric acid (CI) and gallic acid (GA) to the soil material. Values followed by the same letter are not different $(P<0.05)$.

Treatments with a single application of organic acids resulted in low metal solubility (Figure 1). This is clearly due to the high biodegrability of natural organic acids in soil (Krishnamurti et al., 1997; Ström et al., 2001). The citric acid three-application treatment presented the highest $\mathrm{Cd}$ concentration in solution (36.90 $\left.\mathrm{mg} \mathrm{L}^{-1}\right)$ whereas one single application of such acid resulted in a soluble Cd concentration $32 \%$ lower $\left(25 \mathrm{mg} \mathrm{L}^{-1}\right)$. Successive applications of citric acid can suppress the negative effect of its high degradation rate, increasing the efficiency of chemically-assisted phytoextraction. On the other hand, the highest concentration of $\mathrm{Cd}$ in soil solution after gallic acid addition resembled the one obtained by the single citric acid application. This dem- onstrates the low ability of gallic acid to solubilize $\mathrm{Cd}$ in soils.

The $\mathrm{Pb}$ concentration in soil solution increased 97 and $81 \%$ after three applications of the citric and gallic acid, respectively (Figure 1). For the citric acid treatments, the largest $\mathrm{Pb}$ concentration was $18 \mathrm{mg}$ $\mathrm{L}^{-1}$, and the smallest $5 \mathrm{mg} \mathrm{L}^{-1}$, representing a $72 \%$ reduction in six days after the chelant application. Such decrease in $\mathrm{Pb}$ concentration was lower for the gallic acid (46\%), i.e., from $3.15 \mathrm{mg} \mathrm{L}^{-1}$ to $1.7 \mathrm{mg} \mathrm{L}^{-1}$ in the same stage. This demonstrates both the lower ability to solubilize $\mathrm{Pb}$ and the slower biodegrability of gallic acid as compared to citric acid. In spite of the high percentage increase, neither citric nor gallic acid seem to be able to of solubilize $\mathrm{Pb}$ at suitable levels for effi- 
cient phytoextraction, even when applied three successive times. Tamura et al. (2005), Nascimento (2006) and Evangelou et al. (2006) demonstrated the low ability of LMWOA to bring less soluble metals (such as $\mathrm{Pb}$ ) into soil solution. This is a serious drawback for phytoextraction with these chelants in $\mathrm{Pb}$ contaminated soils. So far only synthetic chelants such as EDTA (Blaylock et al., 1997), EDDS (Kos \& Lestan, 2004) and MGDA (Tamura et al., 2005) are effective for lead phytoextraction.

The single, double and triple application of gallic acid did not differ regarding $\mathrm{Cu}$ concentration in soil solution (Figure 1), although they get a $50 \%$ increase in the metal solubility as compared to control. On the other hand, the citric acid three-time application was significantly more efficient in solubilizing $\mathrm{Cu}$ (81.53 $\left.\mathrm{mg} \mathrm{L}^{-1}\right)$. Accordingly, high $\mathrm{Cu}$ mobility in soil treated with organic acids, especially citric acid, was observed (Evangelou et al., 2006). In such a case, the $\mathrm{Cu}$ concentration in the soil solution increased $90 \%$ as compared to control. The $\mathrm{Cu}$ concentration between the first and third application decreased $66 \%$, indicating the high citric acid degradability. The lowest value of $\mathrm{Zn}$ concentration in soil solution after citric acid application was $182 \mathrm{mg} \mathrm{L}^{-1}$; after three applications, this figure reached $304 \mathrm{mg} \mathrm{L}^{-1}$. Similarly to $\mathrm{Cd}$, the lowest concentration of $\mathrm{Zn}$ in citric acid treatments was equivalent to the highest one obtained by gallic acid application. Once more this demonstrates the low potential of gallic acid when used in phytoextraction, even for fairly soluble metals.

LMWOA application to soil did not promote an increase in the velvet shoots heavy metal concentrations (Table 2). Similar results were reported to other species by Chen et al. (2003), Turgut et al. (2004),
Luo et al. (2005) and Meers et al. (2005). It can be explained as an effect of the fast mineralization of soil organic acids (Römkens et al., 2002). Synthetic chelators applied to soil at $5 \mathrm{mmol} \mathrm{\textrm {kg } ^ { - 1 }}$ can solubilize much higher amounts of metals than LMWOA applied at $20 \mathrm{mmol} \mathrm{kg}^{-1}$ rates (Nascimento, 2006). The low root biomass production resulting from metal toxicity (Table 1) limited the efficiency of metal extraction by velvet bean, since there was a substantial increase in the metals availability via LMWOA addition (Figure 1). It also suggests that using tolerant or hyperaccumulator species, associated with successive applications of LMWOA, could be a viable approach. Plant's tolerance to metal stress is certainly a key factor to successful phytoextraction and hampers the feasibility of this technique.

Root metal concentration increase through organic acids application was observed only to $\mathrm{Pb}$ (Table 2 ). This is probably a consequence of the naturally low mobility of such metal in soil. However, the low affinity ( $\log K_{s}=6.5$ ) of $\mathrm{Pb}$ for citric acid (Römkens et al., 2002) suggests their low ability to substantially increase the $\mathrm{Pb}$ translocation to shoots. Actually, only synthetic chelants seem to be capable of hastening the $\mathrm{Pb}$ transport to shoots up to levels proper to phytoextraction (Blaylock et al., 1997; Tamura et al., 2005).

The phytoextraction efficiency can be evaluated by the net removal of metals from soils rather than by the concentration of metals in shoots. As it can be seen in Figure 2 LMWOA increased the removal of $\mathrm{Pb}, \mathrm{Cu}$ and $\mathrm{Zn}$ from soil, except for a single application of citric acid for $\mathrm{Zn}$. The amount of $\mathrm{Cd}$ removed by plants upon LMWOA addition was not higher than in control. This can be related to the soil high avail-

Table 2 - Metals concentration in velvet bean shoots and roots, according to three different application times (one, two, and three applications).

\begin{tabular}{|c|c|c|c|c|c|c|c|}
\hline \multirow{2}{*}{ Metal } & \multirow{2}{*}{ Control } & \multicolumn{3}{|c|}{ Citric acid } & \multicolumn{3}{|c|}{ Gallic acid } \\
\hline & & 1 Appl. & 2 Appl. & 3 Appl. & 1 Appl. & 2 Appl. & 3 Appl. \\
\hline & $-\cdots-1$ & 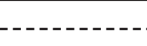 & ---1 & $-\mu \mathrm{g} \mathrm{kg}$ & - & 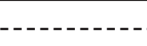 & - \\
\hline & & & & Shoots & & & \\
\hline $\mathrm{Cd}$ & $82.0 \mathrm{a}$ & $80.7 \mathrm{a}$ & $72.7 \mathrm{a}$ & $80.6 \mathrm{a}$ & $72.3 \mathrm{a}$ & $86.3 \mathrm{a}$ & $83.0 \mathrm{a}$ \\
\hline $\mathrm{Pb}$ & $11.5 \mathrm{a}$ & $14.9 \mathrm{a}$ & $12.1 \mathrm{a}$ & $13.9 \mathrm{a}$ & $10.2 \mathrm{a}$ & $11.3 \mathrm{a}$ & $7.8 \mathrm{a}$ \\
\hline $\mathrm{Cu}$ & $52.2 \mathrm{a}$ & $52.6 \mathrm{a}$ & $49.4 \mathrm{a}$ & $51.0 \mathrm{a}$ & $47.5 \mathrm{a}$ & $51.1 \mathrm{a}$ & $50.1 \mathrm{a}$ \\
\hline \multirow[t]{2}{*}{$\mathrm{Zn}$} & $670.4 \mathrm{a}$ & $695.6 \mathrm{a}$ & $701.5 \mathrm{a}$ & $715.2 \mathrm{a}$ & $704.7 \mathrm{a}$ & $772.3 \mathrm{a}$ & $823.7 \mathrm{a}$ \\
\hline & & & & Roots & & & \\
\hline $\mathrm{Cd}$ & $717.9 \mathrm{a}$ & $709.5 \mathrm{a}$ & $674.9 \mathrm{a}$ & $666.4 \mathrm{a}$ & $632.8 \mathrm{a}$ & $660.8 \mathrm{a}$ & $677.9 \mathrm{a}$ \\
\hline $\mathrm{Pb}$ & $975.3 \mathrm{c}$ & $1,650.6 \mathrm{a}$ & $1,294.4 \mathrm{~b}$ & $1,698.1 \mathrm{a}$ & $1,393.5 \mathrm{~b}$ & $1,478.4 \mathrm{a}$ & $1,735.9 \mathrm{a}$ \\
\hline $\mathrm{Cu}$ & $4,287.8 \mathrm{a}$ & $5,049.5 \mathrm{a}$ & $4,287.1 \mathrm{a}$ & $4,616.1 \mathrm{a}$ & $4,451.7 \mathrm{a}$ & $4,225.4 \mathrm{a}$ & $4,648.7 \mathrm{a}$ \\
\hline $\mathrm{Zn}$ & $3,686.5 \mathrm{a}$ & $3,742.9 \mathrm{a}$ & $3,514.2 \mathrm{a}$ & $3,669.1 \mathrm{a}$ & $3,565.9 \mathrm{a}$ & $3,818.9 \mathrm{a}$ & $3,974.0 \mathrm{a}$ \\
\hline
\end{tabular}

Values followed by the same letter in rows are not different (Scott-Knott com $P<0.05$ ). 

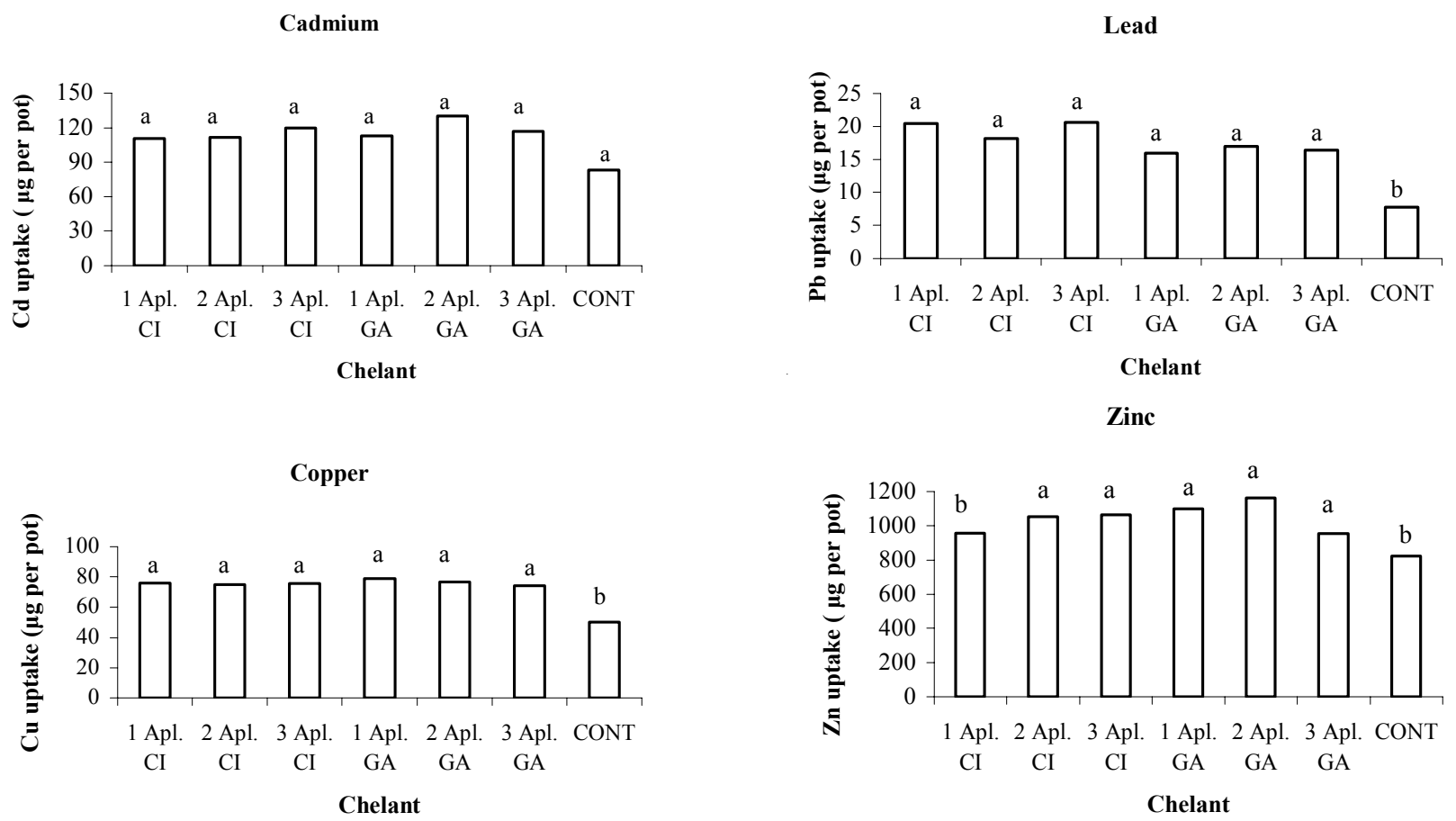

Figure 2 - Removal of $\mathrm{Cd}, \mathrm{Pb}, \mathrm{Cu}$, and $\mathrm{Zn}$ in velvet bean shoots ( $\mu \mathrm{g}$ per pot) grown in soil material treated with gallic (GA) and citric (CI) acids applied in three forms $(1,2$, and 3 applications $)$ at a $5 \mathrm{mmol} \mathrm{kg}^{-1}$ rate. Values followed by the same letter are not different $(P<0.05)$.

ability of Cd. Gallic and citric acid are not able to increase the phytoextraction of $\mathrm{Pb}$ from soil (Nascimento et al., 2006). For instance, citric acid had no effect on $\mathrm{Pb}$ uptake by common buckwheat even when the soil was treated with a high concentration $\left(20 \mathrm{mmol} \mathrm{kg}{ }^{-1}\right)$ of this chelant (Tamura et al., 2005). These results corroborate the low potential of LMWOA for $\mathrm{Pb}$ phytoextraction.

Cadmium, $\mathrm{Pb}, \mathrm{Cu}$, and $\mathrm{Zn}$ water soluble contents increased accordingly to the successive organic acids applications to soil (Table 3). Contents of $\mathrm{Cd}$, $\mathrm{Pb}$, and $\mathrm{Zn}$ were highest for the three-application treatment of citric acid. The low content of $\mathrm{Cd}$ in iron oxides indicates this metal low affinity for sites of specific adsorption and demonstrates the relatively high solubility of $\mathrm{Cd}$ in soils. The exchangeable concentration of metals was also increased owing to LMWOA addition.

Organic matter fraction retained most of the $\mathrm{Cu}$ and $\mathrm{Zn}$ in soil (Table 3). The concentration of organic matter bounded $\mathrm{Cu}$ and $\mathrm{Zn}$ was reduced as a result of organic acids application. In the more bioavailable fractions (WS and Ex) Zn seemed to be incremented by remobilization from organic matter bounded $\mathrm{Zn}$, which substantially diminished by LMWOA. On the other hand, lead and copper contents in organic matter were almost unaffected by acids addition. This is probably due to the organic matter affinity of $\mathrm{Pb}$ and $\mathrm{Cu}$ which is higher than
$\mathrm{Zn}$ making the $\mathrm{Pb}$ - and $\mathrm{Cu}$-complexes to be more stable.

The LMWOA caused a mobilization of $\mathrm{Pb}$ and $\mathrm{Cu}$ from oxide fractions in soil (Table 3). LMWOA induced metal dissolution in crystalline and/or poorly crystallized soil minerals. Carboxylic groups of LMWOA can dissociate over a wide range of $\mathrm{pH}$, weathering primary minerals and dissolving then by complexation (Sposito, 1989). This is particularly important for poorly available soil metals since they depend on solubilization from stable pools in order to be taken up by plants. However, LMWOA metal mobilization from iron oxides, as observed here, is less impressive when compared to the ability of synthetic chelating agents, such as EDTA (Barona et al., 2001). Thus, if the targets for phytoextraction are metals tightly bound to oxides and to soil residual fraction, the LMWOA tested here do not seem to be a good bet to improve phytoextraction.

\section{CONCLUSIONS}

Multiple applications of citric acid to soil had a positive effect on the mobilization of $\mathrm{Cd}, \mathrm{Pb}, \mathrm{Cu}$, and $\mathrm{Zn}$. However, neither citric acid nor gallic acid was efficient to induce metals phytoextraction. In general, LMWOA application increased the metal concentrations in the water soluble and exchangeable fractions. Zinc and $\mathrm{Cu}$ were retained mostly in the 
Table 3 - Metal concentration in five different soil fractions: water soluble (WS), exchangeable (Ex), organic matter (OM), amorphous iron oxides (AFeOx) and crystalline iron oxides (CFeOx) after addition of chelants to soil (one, two and three applications).

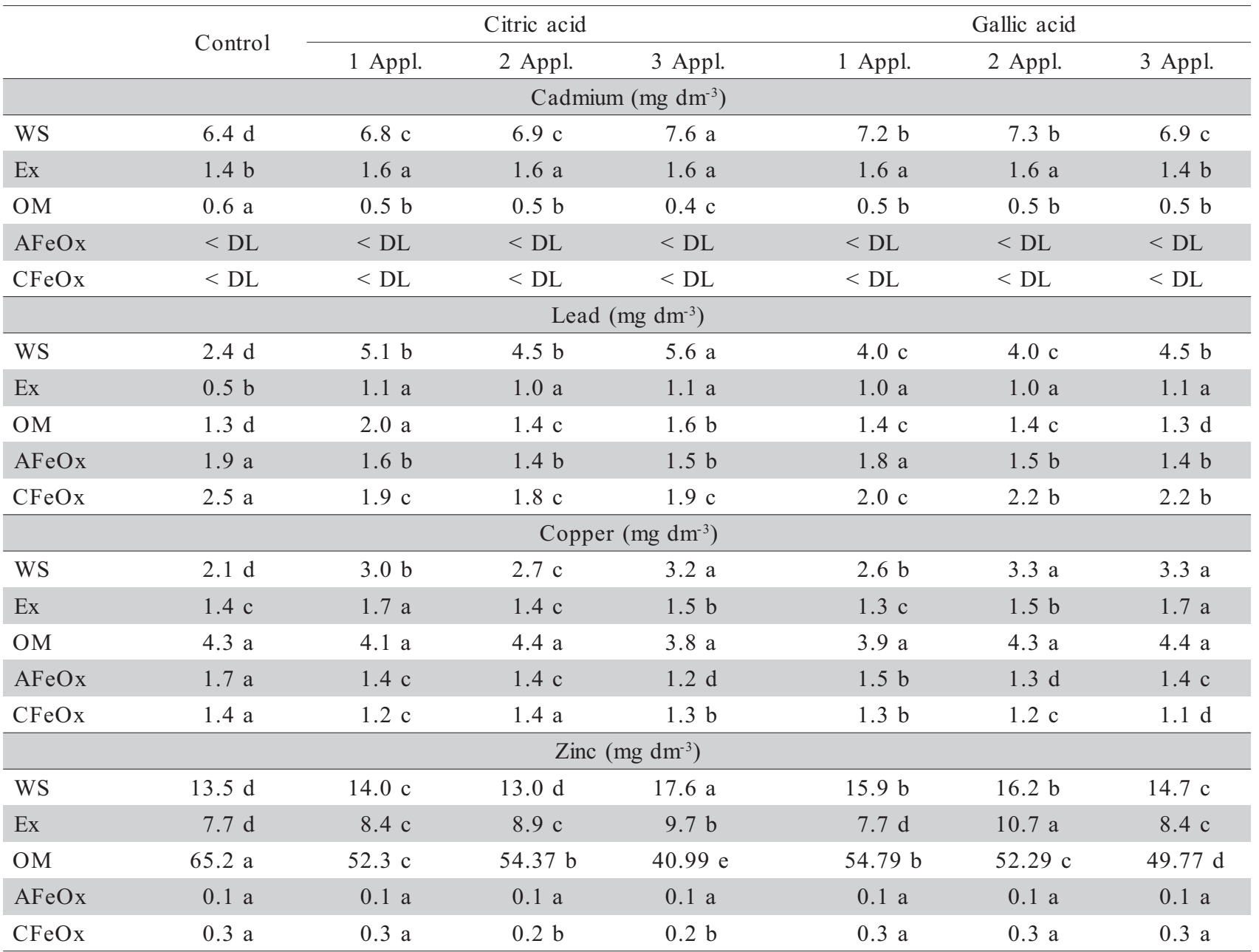

Values followed by the same letter in each row are not different (Scott-Knott $P<0.05$ ). DL - Below detection limit.

organic matter fraction, from where $\mathrm{Zn}$ was remobilized through LMWOA application into the more available water soluble and exchangeable fractions. LMWOA mobilized $\mathrm{Pb}$ and $\mathrm{Cu}$ from iron oxides, but such an increase in solubility was not high enough to affect the phytoextraction. So far the LMWOA tested are not suitable to enhance phytoextraction, even when successively applied, suggesting that more detailed information about a natural LMWOA able to replace synthetic chelants that induce metal phytoextraction is required. Studies on amounts and time of application of LMWOA are also important. Therefore, research must continue searching for natural LMWOA to replace synthetic chelants for metal phytoextraction. More studies on doses and application timing of LMWOA are also needed to make these acids a viable alternative to synthetic chelants.

\section{REFERENCES}

BARONA, A.; ARANGUIZ, I.; ELÍAS, A. Metal associations in soils before and after extractive decontamination: implications for the effectiveness of further clean-up procedures. Environmental Pollution, v.113, p.79-85, 2001.

BLAYLOCK, M.J.; SALT, D.E.; DUSHENKOV, S.; ZAKHAROVA, O.; GUSSMAN, C.; KAPULNIK, Y.; ENSLEY, B.D.; RASKIN, I. Enhanced accumulation of $\mathrm{Pb}$ in Indian mustard by soil applied chelating agents. Environmental Science and Technology, v.31, p.860-865, 1997.

CHAO, T.T.; ZHOU, L. Extraction techniques for selective dissolution of amorphous iron oxides from soils and sediments. Soil Science Society of America Jounal, v.47, p.224-232, 1983.

CHEN, Y.X.; LIN, Q.; LUO, Y.M.; HE, Y.F.; ZHEN, S.J.; YU, Y.L.; TIAN, G.M.; WONG, M.H. The role of citric acid on the phytoremediation of heavy metal contaminated soil. Chemosphere, v.50, p.807-811, 2003.

COOPER, E.M.; SIMS, J.T.; CUNNINGHAM, S.D.; HUANG, J.W., BERTI, W.R. Chelate-assisted phytoextraction of lead from contaminated soils. Journal of Environmental Quality, v.28, p.1709-1719, 1999. 
CUNNINGHAM, S.D.; BERTI, W.R. Phytoextraction and phytoestabilization: technical, economic, and regulatory considerations of soil-lead issue. In: TERRY, N.; BAÑUELOS, G. (Ed.) Phytoremediation of contaminated soil and water. Boca Raton: Lewis, 2000. p.359-376

EVANGELOU, M.W.H.; EBEL, M.; SHAEFFER, A. Evaluation of the effect of small organic acids on phytoextraction of $\mathrm{Cu}$ and $\mathrm{Pb}$ from soil with tobacco Nicotiana tabacum. Chemosphere, v.63, p.996-1004, 2006.

HUANG, J.W.; CHEN, J.; BERTI, W.R.; CUNNINGHAM, S.D. Phytoremediation of lead-contaminated soils: role of synthetic chelates in lead phytoextraction. Environmental Science and Technology, v.31, p.800-805, 1997.

KOS, B.; LESTAN, D. Chelator induced phytoextraction and in situ soil washing of $\mathrm{Cu}$. Environmental Pollution, v.132, p.333-339, 2004.

KRISHNAMURTI, G.S.R.; CIESLINSKI, G.; HUANG, P.M.; VAN PEES, K.C.J. Kinectics of cadmium release from soils as influenced by organic acids: implication in cadmium availability. Journal of Environmental Quality, v.26, p.271-277, 1997.

LOMBI, E.; ZHAO, F.J.; DUNHAM, S.J.; McGRATH, S.P. Phytoremediation of heavy-metal contaminated soils: natural hyperaccumulation versus chemically enhanced phytoextraction. Journal of Environmental Quality, v.30, p.1919-1926, 2001.

LUO, C.; SHEN, Z.; LI, X. Enhanced phytoextraction of $\mathrm{Cu}, \mathrm{Pb}$, $\mathrm{Zn}$ and $\mathrm{Cd}$ with EDTA and EDDS. Chemosphere, v.59, p.111,2005

MEERS, E.; RUTTENS, A.; HOPGOOD, M.J.; SAMSON, D.; TACK, F.M.G. Comparison of EDTA and EDDS as potential soil amendments for enhanced phytoextraction of heavy metals. Chemosphere, v.58, p.1011-1022, 2005.

MELO, E.E.C.; NASCIMENTO, C.W.A.; SANTOS, A.C.Q. Solubilidade, fracionamento e fitoextração de metais pesados após aplicação de agentes quelantes. Revista Brasileira de Ciência do Solo, v.30, p.1051-1060, 2006

NASCIMENTO, C.W.A. Organic acids effects on desorption of heavy metals from a contaminated soil. Scientia Agricola, v.63, p.276-280, 2006.

NASCIMENTO, C.W.A; AMARASIRIWARDENA, D.; XING, B. Comparison of natural organic acids and synthetic chelates at enhancing phytoextraction of metals from a multi-metal contaminated soil. Environmental Pollution, v.140, p.114123,2006

NASCIMENTO, C.W.A.; XING, B. Phytoextraction: a review on enhanced metal availability and plant accumulation. Scientia Agricola, v.63, p.299-311, 2006

NOVOZAMSKY, I.; LEXMOND, T.M.; HOUBA, V.J.G. A single extraction procedure of soil for evaluation of uptake of some heavy metals by plants. International Journal of Environmental and Analytical Chemistry, v.51, p.47-58, 1993.
PROCÓPIO, S.O.; SANTOS, J.B.; PIRES, F.R.; SILVA, A.A.; SANTOS, E.A.; FERREIRA, L.R. Fitorremediação de solos contaminados com tebuthiuron utilizando-se espécies cultivadas para adubação verde. Planta Daninha, v.23, p.719-724, 2005.

RASKIN, I.; SMITH, R.D.; SALT, D.E. Phytoremediation of metals: using plants to remove pollutants from the environment. Current Opinion in Biotechnology, v.8, p.221-226, 1997.

RÖMKENS, P.; BOUWMAN, L.; JAPENGA, J.; DRAAIMA, C. Potentials and drawbacks of chelate-enhanced phytoremediation of soils. Environmental Pollution, v.116, p.109-121, 2002.

SANTOS, A.C.Q. Metais pesados em solos: seleção de espécies acumuladoras, competição entre elementos e uso de silício na fitoextração induzida. Recife: UFRPE, 2006. 62p. Dissertação (Mestrado).

SHEN, Z.G.; LI, X.D.; WANG, C.C.; CHEN, H.M.; CHUA, H. Lead phytoextraction from contaminated soil with high-biomass plant species. Journal of Environmental Quality, v.31, p. $1893-1900,2002$.

SHUMAN, L.M. Fractionation method for soil microelements. Soil Science, v.140, p.11-22, 1985.

SPOSITO, G. The chemistry of soils. New York: Oxford University Press, 1989. 277 p.

STRÖM, L.; OWEN, A.G.; GODBOLD, D.L.; JONES, D.L. Organic acid behaviour in a calcareous soil: sorption reactions and biodegradation rates. Soil Biology and Biochemistry, v.33, p.2125-2133, 2001

TAMURA, H.; HONDA, M.; SATO, T.; KAMACHI, H. Pb hyperaccumulation and tolerance in commom buckwheat (Fagopyrum esculentum Moench). Journal of Plant Research, v.118, p.355-359, 2005.

TERRY, N.; BAÑUELOS, G. Phytoremediation of contaminated soil and water. Boca Raton: Lewis, 2000. p.189-200.

TURGUT, C.; PEPE, M.K.; CUTRIGHT, T.J. The effect of EDTA and citric acid on phytoremediation of $\mathrm{Cd}, \mathrm{Cr}$, and $\mathrm{Ni}$ from soil using Helianthus annuus. Environmental Pollution, v.131, p.147-154, 2004 .

WU, J.; HSU, F.C.; CUNNINGHAM, S.D. Chelate-assisted Pb phytoremediation: $\mathrm{Pb}$ availability, uptake, and translocation constraints. Environmental Science and Technology, v.33, p.1898-1904, 1999.

Received September 13, 2006

Accepted September 26, 2007 